\title{
Plasma levels of norepinephrine and expression levels of ß2-adrenergic receptor gene correlate with the incidence of acute graft-versus-host disease
}

\author{
Zahra Momeni-Varposhti ${ }^{1}$, Mohammad Hossein Kazemi ${ }^{2,3}$, Mehdi Talebi ${ }^{4}$, Rouzbeh Chegeni ${ }^{5}$, Elham Roshandel ${ }^{3}$, \\ Abbas Hajifathali*3 ${ }^{(\mathbb{B})}$, Ali Akbar Movassaghpour*1;(0) \\ Received: 14 Jul 2019 \\ Published: 9 Nov 2020
}

\begin{abstract}
Background: Acute graft-versus-host disease is a major complication in allogeneic hematopoietic stem-cell transplantation. Epinephrine and norepinephrine are stress hormones which affect many cells, including immune cells through interaction with adrenergic receptors, mainly $\beta 2$-adrenergic receptor. The immunomodulatory effects of epinephrine, norepinephrine, and signaling of the adrenergic receptor have been shown to decrease the probability of the acute graft-versus-host disease in animal models. The aim of our study was to investigate the possible correlations between the serum levels of epinephrine and norepinephrine and also leukocytic expression levels of $\beta 2$-adrenergic receptor with the incidence of acute graft-versus-host disease in patients undergoing allogeneic hematopoietic stemcell transplantation.

Methods: In this study, the plasma levels of epinephrine and norepinephrine and the leukocytic expression of $\beta 2$-adrenergic receptor gene were measured and compared in allogeneic hematopoietic stem-cell transplantation patients with and without acute graft-versushost disease. Data were analyzed and illustrated using SPSS 19 and GraphPad Prism 6. The student T-test, Pearson, and Spearman's tests were performed and $\mathrm{p}<0.05$ was considered as significant.

Results: We showed that the plasma levels of norepinephrine and the relative amount of the mRNA of $\beta 2$-adrenergic receptor at 7 and 21 days after allogeneic hematopoietic stem-cell transplantation were significantly lower in patients with acute graft-versus-host disease than recipients without acute graft-versus-host disease. There were also negative correlations between the plasma levels of norepinephrine, leukocytic levels of the mRNA of $\beta 2$-adrenergic receptor, and the incidence of acute graft-versus-host disease.

Conclusion: Our results suggest that stress hormones and their receptor might have a role in preventing acute graft-versus-host disease and could be promising factors in controlling the outcome of allogeneic hematopoietic stem-cell transplantation.
\end{abstract}

Keywords: Norepinephrine, Epinephrine, $\beta 2$-adrenergic receptor, Acute graft-versus-host disease

Conflicts of Interest: None declared

Funding: The project was funded by Hematology and Oncology Research Center, Tabriz University of Medical Sciences, Tabriz, Iran.

\section{*This work has been published under CC BY-NC-SA 1.0 license.}

Copyright $\odot$ Iran University of Medical Sciences

Corresponding authors: Dr Ali Akbar Movassaghpour, movassaghpour@tbzmed.ac.ir DrAbbas Hajifathali, hajifathali@yahoo.com

1. Hematology and Oncology Research Center, Tabriz University of Medical Sciences, Tabriz, Iran

2. Student Research Committee, Department of Immunology, School of Medicine, Iran University of Medical Sciences, Tehran, Iran

3. Hematopoietic Stem Cell Research Center, Shahid Beheshti University of Medical Sciences, Tehran, Iran

4. Department of Applied Cell Sciences, School of Advance Medical Sciences, Tabriz University of Medical Sciences, Tabriz, Iran

5. The Michener Institute of Education, University Health Network, Toronto, Canada $\uparrow$ What is "already known" in this topic:

The previous findings indicate the beneficial effects of norepinephrine and signaling of $\beta 2$-adrenergic receptor on the modulation of the immune system and resistance to acute graftversus-host disease in animal models. However, no investigation has been conducted to confirm this association in humans so far.

\section{$\rightarrow$ What this article adds:}

We showed that the plasma levels of norepinephrine and leukocytic expression of $ß 2$-adrenergic receptor gene negatively correlates with the incidence of acute graft-versus-host disease, suggesting that this axis might have a role in the prevention of acute graft-versus-host disease and could be promising factors in controlling the outcome of allogeneic hematopoietic stem-cell transplantation. 
Cite this article as: Momeni-Varposhti Z, Kazemi MH, Talebi M, Chegeni R, Roshandel E, Hajifathali A, Movassaghpour AA. Plasma levels of norepinephrine and expression levels of $\beta 2$-adrenergic receptor gene correlate with the incidence of acute graft-versus-host disease. Med $J$ Islam Repub Iran. 2020 (9 Nov);34:151. https://doi.org/10.47176/mjiri.34.151

\section{Introduction}

Allogeneic hematopoietic stem cell transplantation (alloHSCT) was a revolution in the treatment of hematologic malignancies. Despite the benefits of allo-HSCT, acute graft-versus-host disease (aGvHD) is of a major posttransplantation complication accounts for the majority of mortalities in patients (1). The main contributors involved in the pathogenesis of GvHD are antigen-presenting cells (APCs) and T lymphocytes, whose removal before transplantation leads to a reduction in the beneficial effects of graft-versus-tumor (GvT) (2). Researchers are looking for ways to enhance the recipient's immune system and control the aGvHD. Studies in recent decades have shown the reciprocal interaction of the nervous and the immune systems $(3,4)$. Several studies reported the effects of neurotransmitters on various immune cells, including APCs and lymphocytes (5-7). Two important hormones of the sympathetic nervous system (SNS), which affect the function of the immune system are epinephrine and norepinephrine. These hormones act through adrenergic receptors present on many cell types, including immune cells. The association between high serum norepinephrine levels, $\beta$-adrenergic receptor signaling, APC and T lymphocyte activation has been reported in various conditions including transplantation (7-9) .In the conditions of tumor or infectious disease in which immune suppression exacerbates the disease condition (10-12), studies have shown that neurotransmitters, particularly epinephrine and norepinephrine, through adrenergic receptor signaling in immune cells can modulate the anti-tumor functions of the immune system (13). In other circumstances such as GvHD in which a regulated immune system is desirable, the neurologic-mediated immune-modulation is beneficial to mitigate the consequences and control the disease (8). Mouse models have shown that cold stress due to increased serum norepinephrine levels and increased signaling of $\beta 2$-adrenergic receptors $(\beta 2-\mathrm{AR})$ can enhance the host immune system leading to resistance to acute GvHD. The GvHD-resistance was eliminated in $\beta 2-\mathrm{AR}^{-/-}$mice and mice treated with $\beta 2-\mathrm{AR}$ blockers (8). These studies indicate the beneficial effects of norepinephrine and $\beta 2$-AR signaling on the immune system and resistance to aGvHD in animal models. However, no investigation has been conducted to confirm this association in humans so far. In this study, serum epinephrine and norepinephrine levels, expression of $\beta 2$-adrenergic receptor and their associations with the incidence of aGvHD in patients undergoing allo-HSCT were investigated which might open a new window for the role of short-term stress in patients undergoing hematopoietic stem cell transplantation.

\section{Methods \\ Patients}

Fifteen patients (median age of 38 years old) diagnosed with acute myeloid leukemia and candidates for allo-HSCT were randomly selected from the HSCT and Cell Therapy Center at Taleghani Hospital of Tehran, Iran. All patients received full 6/6 human leukocyte antigen (HLA) matched grafts. At days $-7,0,+7$, and +21 (day of transplantation was considered as day 0 ), $5 \mathrm{~mL}$ of peripheral blood samples were collected in EDTA containing tube and the plasma samples were isolated and preserved at $-80^{\circ} \mathrm{C}$. Patients were followed-up for 100 days after transplantation to determine the presence or absence of aGvHD based on the patients' clinical manifestations and NIH criteria (14). The demographic and clinical data of patients are shown in Table 1. All candidates have given informed consent, and the study received ethics approval by the university ethics committee.

\section{Epinephrine and norepinephrine quantification by ELISA}

The plasma levels of epinephrine and norepinephrine were measured using quantitative competitive enzymelinked immunosorbent assay ELISA following the manufacturer's protocol (ELISA Fast Track, LDN, Nordhorn, Germany). Briefly, epinephrine and norepinephrine were extracted using a cis-diol-specific affinity gel, then acylated and enzymatically converted. The antigen was bound to the microtiter plate solid phase and competed with the standards, controls and patients' plasma in binding to the antibody. The solid phase-bound antibody was detected by an anti-rabbit peroxidase conjugate. The sensitivity of kits for epinephrine and norepinephrine were 0.018 and 0.093 $\mathrm{ng} / \mathrm{ml}$, respectively. The specificity of both ELISA kits for their specific analytes was $100 \%$ and for other related analytes such as dopamine, metanephrine, normetanephrine, tyramine ant etc. were less than $0.2 \%$.

\section{RNA extraction and CDNA synthesis}

Buffy coats were isolated by centrifugation of $3 \mathrm{ml}$ of anticoagulated whole blood and washed with phosphate buffer saline (PBS). Total RNA extraction was performed using Trizol reagent (Invitrogen, Carlsbad, CA). One $\mathrm{mL}$ Trizol was added to $200 \mu \mathrm{l}$ of buffy coat and after $5 \mathrm{~min}$ incubation at room temperature and centrifugation at 1000 $\mathrm{g}$ for $15 \mathrm{~min}$ at $4^{\circ} \mathrm{C}, 200 \mu \mathrm{l}$ cold Chloroform was added, and the sample was centrifuged for $15 \mathrm{~min}$ at $1000 \mathrm{~g}$ and $4^{\circ} \mathrm{C}$. $500 \mu \mathrm{l}$ of isopropanol was added to isolated supernatant and incubated for an extra $15 \mathrm{~min}$ at $4^{\circ} \mathrm{C}$ followed by the same centrifugation protocol. The pellet was re-suspended in $0.5 \mathrm{ml}$ of $75 \%$ ethanol and then left out to dry. The recovered RNA was eluted in diethyl pyrocarbonate (DEPC) water. The quantity and quality of extracted RNA were evaluated by the NanoDrop spectrophotometer using an optical density (OD) ratio of $260 \mathrm{~nm} / 280 \mathrm{~nm}$. A ratio of 1.8 to 2 is acceptable. The integrity of each RNA extracted samples was verified by running on $(1 \% \mathrm{w} / \mathrm{v})$ RNase-free 
agarose gel and visualization of SYBR Safe stain (Invitrogen, CA) under ultra-violet light. The reverse transcription of extracted RNA into first-strand complementary DNA (cDNA) was performed using RevertAid First Strand cDNA Synthesis Kit (thermo-scientific, Lithuania), according to the manufacturer protocol. The positive control was ABL RNA (40 ng/ $\mu \mathrm{l})$.

\section{Relative quantitative real-time PCR}

The mRNA expression levels of the $\beta 2$-adrenergic receptor were relatively quantified by quantitative-PCR (qPCR) using RealQ Plus Master Mix Green + ROX (Ampliqon, Odense, Denmark) on Step One Real-Time PCR System thermocycler (Applied Biosystems). gene-specific primers for $\beta 2$ adrenergic receptor were used for real-time-PCR reaction (forward: 5'-TTCTTGCTGGCA CCCAATGGAAG-3', reverse 5'-CCAGTGAAGTGA TGAAGTTGGTG-3') (13) The ABL gene was selected as the reference gene (forward: 5'-TGTGATTATAGC CTAAGACCCGGAG-3', reverse 5'-CAGCGGCCAGTA GCATCTGACTT-3) (15). The amount of $0.5 \mathrm{mM}$ of primers and $2 \mu \mathrm{l}$ of template cDNA were added to $10 \mu \mathrm{l}$ of Master mix and topped-up to $20 \mu \mathrm{l}$ with nuclease-free water. The amplification setting was: $5 \mathrm{~min}$ at $95^{\circ} \mathrm{C}$ followed by 40 cycles of $94^{\circ} \mathrm{C}$ for $30 \mathrm{~s}, 58^{\circ} \mathrm{C}$ for $30 \mathrm{~s}$, and $72^{\circ} \mathrm{C}$ for $15 \mathrm{~s}$. Melting analysis was conducted on the samples to ensure amplification specificity. The results of the melting curve were analyzed as cycle threshold $(\mathrm{Ct})$. The mean $\mathrm{Ct}$ values were normalized to $\mathrm{ABL}$ expression levels $(\Delta \mathrm{Ct}) .2^{-}$ $\Delta \Delta \mathbf{C T}$ method was used to evaluate the relative mRNA expression levels of the target gene (16).

\section{Statistical Analysis}

All experiments were performed in duplicate for each sample. The data were analyzed and illustrated using SPSS version 19 and GraphPad Prism version 6. The normality of the data distribution was evaluated by the KolmogorovSmirnov test. Using the normal distribution of data, parametric analyses (student T-test and Pearson) were carried out. The Spearman's test was performed to study the correlations of epinephrine, norepinephrine, and gene expression with aGvHD status and also, the Pearson tests were used to determin e correlations between epinephrine, norepinephrine and gene expression levels. Moreover, the factor association of Eta-squared was determined to evaluate the perfect association. P-value $<0.05$ was considered as significant.

\section{Results}

\section{Plasma levels of norepinephrine and epinephrine}

Five patients out of 15 recipients (33.3\%) developed aGvHD (Table 1). The patients' plasma levels of norepinephrine and epinephrine at days $-7,0,+7$, and +21 were quantitated using ELISA. The plasma levels of norepinephrine were higher in the non-aGvHD group compared to the aGvHD group (Fig. 1 A). The norepinephrine levels were significantly higher at days $+7 \quad(\mathrm{p}<0.001)$ and +21 $(p<0.001)$. No significant differences were observed at any time point in the plasma levels of epinephrine between the two groups. As it is shown in Figure $1 \mathrm{~B}$, the plasma levels of epinephrine in aGvHD group was slightly higher before allo-HSCT (53 pg/mL in aGvHD groups and $42.5 \mathrm{pg} / \mathrm{mL}$ in

Table 1. Demographic and clinical data of patients

\begin{tabular}{|c|c|c|c|c|c|c|c|c|c|}
\hline $\begin{array}{l}\text { Patient } \\
\text { No. }\end{array}$ & Sex & Age & $\begin{array}{l}\text { Diagno- } \\
\text { sis }\end{array}$ & GvHD status & $\begin{array}{c}\text { Conditioning reg- } \\
\text { imen }\end{array}$ & Donor & $\begin{array}{c}\text { CD3 } \\
\left(\times 10^{6} / \mathrm{kg}\right)\end{array}$ & $\begin{array}{c}\text { CD34 } \\
\left(\times 10^{6} / \mathrm{kg}\right)\end{array}$ & GvHD prophylaxis \\
\hline 1 & $\begin{array}{c}\mathrm{Fe}- \\
\text { male }\end{array}$ & 46 & AML & $\mathrm{NO}$ & $\begin{array}{c}\text { Busulfan }+ \\
\text { Fludarabine }\end{array}$ & Brother & 410 & 4 & $\begin{array}{l}\text { Methotrexate }+\mathrm{Cy}- \\
\text { closporine A }\end{array}$ \\
\hline 2 & Male & 31 & AML & $\mathrm{NO}$ & $\begin{array}{c}\text { Busulfan }+ \\
\text { Fludarabine }\end{array}$ & Brother & 310 & 5.8 & $\begin{array}{c}\text { Methotrexate }+\mathrm{Cy}- \\
\text { closporine A }\end{array}$ \\
\hline 3 & Male & 50 & AML & $\mathrm{NO}$ & $\begin{array}{l}\text { Busulfan }+ \\
\text { Fludarabine }\end{array}$ & Brother & 300 & 3.8 & $\begin{array}{l}\text { Methotrexate }+\mathrm{Cy}- \\
\text { closporine A }\end{array}$ \\
\hline 4 & Male & 25 & AML & $\mathrm{NO}$ & $\begin{array}{c}\text { Busulfan }+ \\
\text { Fludarabine }\end{array}$ & Sister & 151 & 4.9 & $\begin{array}{l}\text { Methotrexate }+\mathrm{Cy}- \\
\text { closporine A }\end{array}$ \\
\hline 5 & $\begin{array}{l}\text { Fe- } \\
\text { male }\end{array}$ & 29 & AML & $\mathrm{NO}$ & $\begin{array}{l}\text { Busulfan }+ \\
\text { Fludarabine }\end{array}$ & Brother & 265 & 3.2 & $\begin{array}{l}\text { Methotrexate }+\mathrm{Cy}- \\
\text { closporine A }\end{array}$ \\
\hline 6 & Male & 47 & AML & $\mathrm{NO}$ & $\begin{array}{l}\text { Busulfan }+ \\
\text { Fludarabine }\end{array}$ & Sister & 360 & 3.5 & $\begin{array}{l}\text { Methotrexate }+\mathrm{Cy}- \\
\text { closporine A }\end{array}$ \\
\hline 7 & Male & 24 & AML & $\mathrm{NO}$ & $\begin{array}{c}\text { Busulfan }+ \\
\text { Fludarabine }\end{array}$ & Brother & 273 & 2.1 & $\begin{array}{c}\text { Methotrexate }+\mathrm{Cy}- \\
\text { closporine A }\end{array}$ \\
\hline 8 & Male & 23 & AML & $\mathrm{NO}$ & $\begin{array}{l}\text { Busulfan }+ \\
\text { Fludarabine }\end{array}$ & Brother & 273 & 3.5 & $\begin{array}{l}\text { Methotrexate }+\mathrm{Cy}- \\
\text { closporine A }\end{array}$ \\
\hline 9 & Male & 28 & AML & $\mathrm{NO}$ & $\begin{array}{c}\text { Busulfan }+ \\
\text { Fludarabine }\end{array}$ & Brother & 390 & 6.9 & $\begin{array}{l}\text { Methotrexate }+\mathrm{Cy}- \\
\text { closporine A }\end{array}$ \\
\hline 10 & Male & 31 & AML & NO & $\begin{array}{l}\text { Busulfan }+ \\
\text { Fludarabine }\end{array}$ & Sister & 350 & 6 & $\begin{array}{l}\text { Methotrexate }+\mathrm{Cy}- \\
\text { closporine A }\end{array}$ \\
\hline 11 & $\begin{array}{l}\mathrm{Fe}- \\
\text { male }\end{array}$ & 41 & AML & Acute & $\begin{array}{c}\text { Busulfan }+ \\
\text { Fludarabine }\end{array}$ & Brother & 330 & 2.37 & $\begin{array}{l}\text { Methotrexate }+\mathrm{Cy}- \\
\text { closporine A }\end{array}$ \\
\hline 12 & Male & 25 & AML & Acute & $\begin{array}{l}\text { Busulfan }+ \\
\text { Fludarabine }\end{array}$ & Brother & 435 & 5.5 & $\begin{array}{l}\text { Methotrexate }+\mathrm{Cy}- \\
\text { closporine A }\end{array}$ \\
\hline 13 & $\begin{array}{l}\text { Fe- } \\
\text { male }\end{array}$ & 17 & AML & Acute & $\begin{array}{c}\text { Busulfan }+ \\
\text { Fludarabine }\end{array}$ & Sister & 365 & 2.8 & $\begin{array}{l}\text { Methotrexate }+\mathrm{Cy}- \\
\text { closporine A }\end{array}$ \\
\hline 14 & Male & 30 & AML & Acute & $\begin{array}{l}\text { Busulfan }+ \\
\text { Fludarabine }\end{array}$ & Sister & 230 & 5.8 & $\begin{array}{l}\text { Methotrexate }+\mathrm{Cy}- \\
\text { closporine A }\end{array}$ \\
\hline 15 & $\begin{array}{l}\mathrm{Fe}- \\
\text { male }\end{array}$ & 27 & AML & Acute & $\begin{array}{c}\text { Busulfan }+ \\
\text { Fludarabine }\end{array}$ & Sister & 335 & 4.5 & $\begin{array}{l}\text { Methotrexate }+\mathrm{Cy}- \\
\text { closporine A }\end{array}$ \\
\hline
\end{tabular}



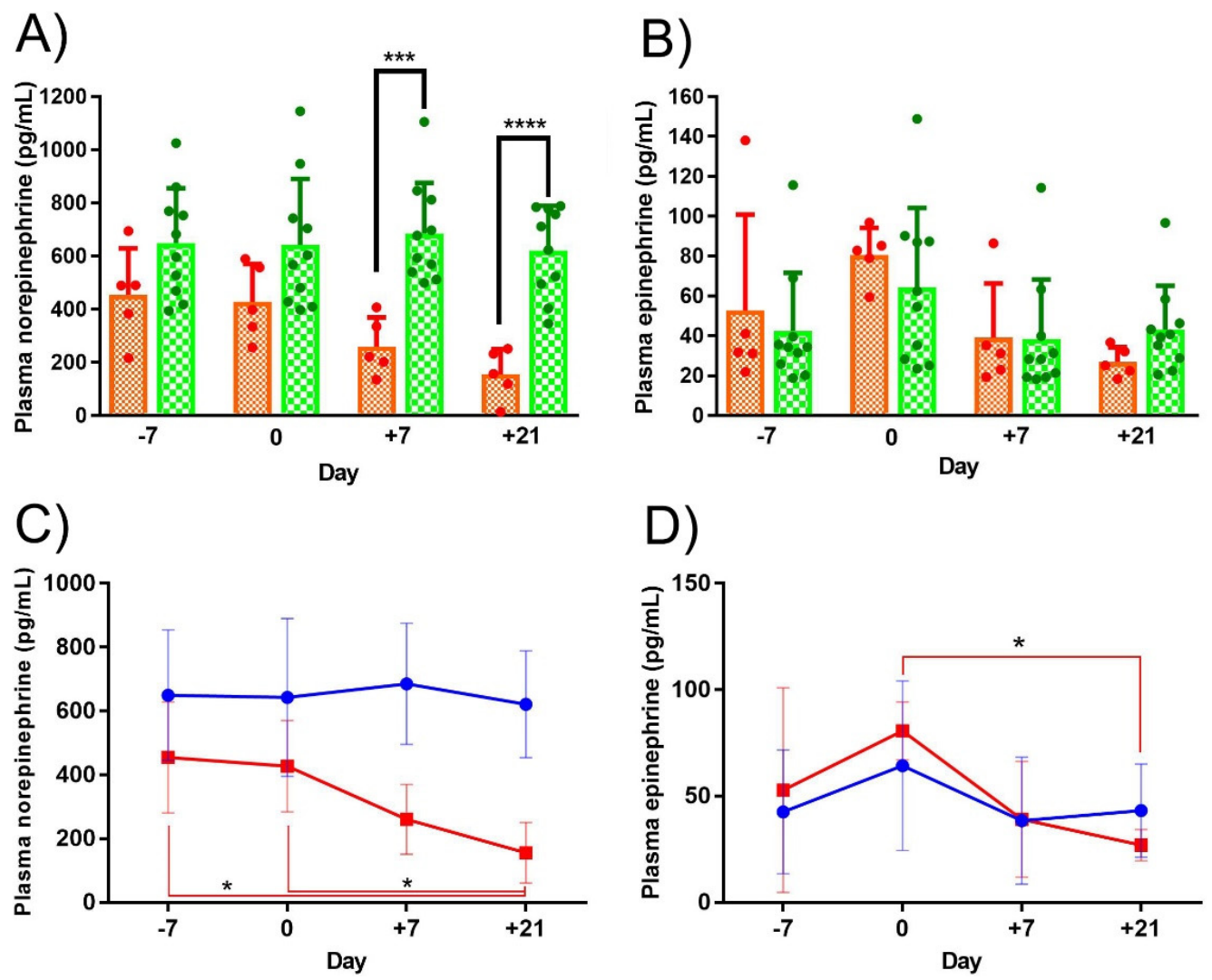

Fig. 1. Plasma levels of norepinephrine and epinephrine in aGvHD and Non-aGvHD groups. The blood samples were taken at days $-7,0$ (The day of allo-HSCT), +7 , and +21 and the plasma levels of NE and E were measured using ELISA. Data shown in bar-chart for norepinephrine (A) and epinephrine (B) with mean and standard deviation. Independent student t-test was used to compare the two groups. Dots represent individuals in each group. The trends of mean plasma levels of norepinephrine (C), epinephrine (D) were displayed in aGvHD and Non-aGvHD groups across four days of sampling. The significant differences are shown in figures by the stars on lines with the same color of the analyzed group. In both (C) and (D) graphs there were only significant differences in aGvHD group (red line). ${ }^{*} \mathrm{p}<0.05,{ }^{* * *} \mathrm{p}<0.001,{ }^{* * * *} \mathrm{p}<0.0001$. aGvHD. Acute Graftversus-Host Disease; $\mathrm{pg} / \mathrm{mL}$. picogram per milliliter.

Non-aGvHD group). After transplantation, the plasma levels of epinephrine in aGvHD patients gradually decreased and fell below the levels of epinephrine in Non-aGvHD group on day $+21(27 \mathrm{pg} / \mathrm{mL}$ in aGvHD groups and 43 $\mathrm{pg} / \mathrm{mL}$ in Non-aGvHD group). The plasma levels of norepinephrine in Non-aGvHD patients showed a steady-state trend with the mean rang of about 620 to $680 \mathrm{pg} / \mathrm{mL}$ while patients who developed aGvHD had a decreasing trend in which the mean plasma levels at day $+21(\approx 155 \mathrm{pg} / \mathrm{mL})$ were significantly lower than those of day -7 and day 0 $(\approx 455 \mathrm{pg} / \mathrm{mL}$ ) (Fig. 1 C). Plasma epinephrine levels had fluctuations across all time-points in both groups. Specifically, at day 0 it increased in both groups and had a significant difference compared to the day +21 . The fluctuation range of epinephrine in aGvHD group was approximately $28-70 \mathrm{pg} / \mathrm{mL}$ and in Non-aGvHD group was about 39-64 $\mathrm{pg} / \mathrm{mL}$ (Fig. 1 D). There were significant differences in norepinephrine levels in aGvHD group at the day +21 compared to day $-7(\mathrm{p}=0.013)$ and the day $0(\mathrm{p}=0.026)($ Fig. 1 C). There was also a significant difference in the levels of epinephrine in the aGvHD group between day 0 and +21 $(\mathrm{p}=0.041)($ Fig. 1 D).

\section{Expression levels of 62-adrenergic receptor gene}

The mRNA expression levels of the $\beta 2$-adrenergic receptor were relatively quantified using real-time $\mathrm{PCR}$ and normalized to the expression levels of the ABL gene. Results have been illustrated as the relative expression of the $\beta 2$ AR gene in two groups in Figure 2 A. $\beta 2$-AR expression was significantly higher in Non-aGvHD patients on days +7 and +21 compared with the aGvHD group $(p<0.001)$. To examine the extent to which the expression of $\beta 2$-AR is higher in Non-aGvHD group, a ratio was developed such that the expression level of $\beta 2$-AR in each group was divided by the expression levels of $\beta 2-\mathrm{AR}$ in the aGvHD group. This way the expression level of $\beta 2-\mathrm{AR}$ in aGvHD group was always 1 and the relative expressions of $\beta 2-\mathrm{AR}$ in Non-aGvHD group was calculated and illustrated in Figure $2 \mathrm{~A}$. The fold changes of $\beta 2-\mathrm{AR}$ expression in NonaGvHD group was shown as a trend across all time points in Figure 2 B. The expression levels of the $\beta 2-\mathrm{AR}$ in NonaGvHD group were 1.37, 1.91, 4.35 and 5.55-fold higher than aGvHD patients in four sampling days, respectively. The relative expression of the $\beta 2$-AR gene in fold change mode showed a gradual increase in Non-aGvHD group. Besides, the inter-day comparisons of $\beta 2$-AR relative expres- 
A)

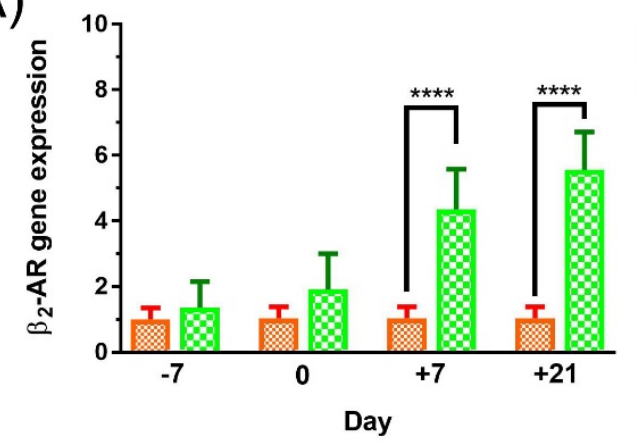

B)

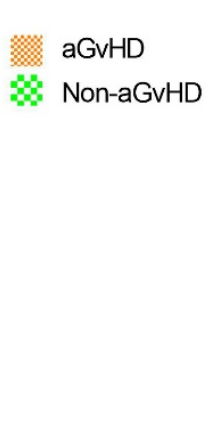

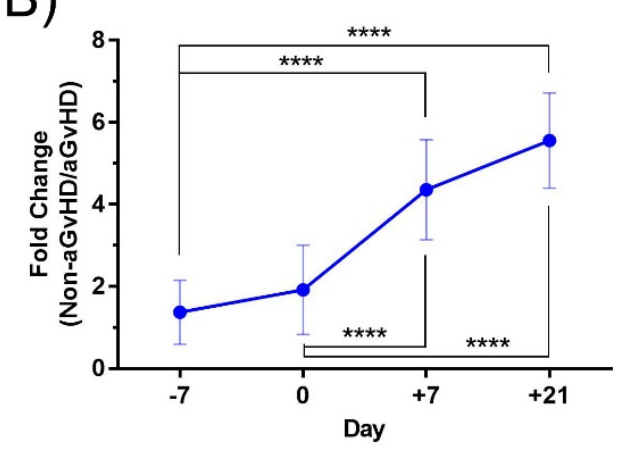

Fig. 2. Gene expression of $\beta 2-A R$ in aGvHD and Non-aGvHD groups. Blood samples were collected at $-7,0$ (The day of allo-HSCT), +7 , and +21 . Total RNA was extracted from buffy coats and synthesized cDNA was used as a template to evaluate the mRNA expression of $\beta 2$-AR. The graph (A) illustrated the relative expression of the $\beta 2$-AR gene. The expression levels of $\beta 2$-AR in both groups are divided by the expression levels of $\beta 2-$ AR in aGvHD group. The error bar represents standard deviation. Independent student t-test was used to compare the two groups. Also, the fold change of $\beta 2$-AR gene expression by dividing the expression levels of $\beta 2-A R$ in Non-aGvHD group by the expression levels of $\beta 2$-AR in aGvHD group were shown as a trend across four time-points in graph (B). The significant inter-days differences were shown by stars. $* * * * \mathrm{p}<0.0001$. aGvHD. Acute Graft-versus-Host Disease; $\beta 2$-AR. $\beta 2$-Adrenergic Receptor;

sion in Non-aGvHD group showed that there were significant differences between the day +7 and +21 compared to the days -7 and $0(\mathrm{p}<0.001)$ (Fig. 2 B).

\section{Correlations between plasma levels of norepinephrine,} epinephrine, and 62-AR gene expression with aGvHD incidence

To study the correlations of the plasma levels of norepinephrine, epinephrine, and $\beta 2-\mathrm{AR}$ gene expression with aGvHD incidence, the Spearman's test was used and the Pearson test was performed to determine the correlation of parametric variables including plasma levels of norepinephrine, epinephrine, and expression levels of $\beta 2-\mathrm{AR}$ gene together. The factor association of Eta-squared was determined to evaluate the perfect association. Only significant correlations were illustrated in Table 2 with the related P-value and correlation coefficient. There were negative correlations between the levels of norepinephrine, $\beta 2$ -
AR gene expression and the incidence of aGvHD on days +7 and +21 . The epinephrine levels have no correlation with other measured components, except for the $\beta 2-\mathrm{AR}$ gene expression on day +21 and some inter-days correlations of epinephrine levels. Some of the inter-days correlations in norepinephrine and also $\beta 2-\mathrm{AR}$ gene expression levels are significant. In addition, there are several positive correlations between norepinephrine and the $\beta 2-\mathrm{AR}$ expression (Table 2).

\section{Discussion}

In this study, for the first time, we have shown that patients with higher norepinephrine and $\beta 2-\mathrm{AR}$ expression are less susceptible to the development of aGvHD. This finding is in agreement with the animal study showing increased levels of norepinephrine due to mild cold stress can reduce GvHD incidence (8). Using $\beta 2$-AR agonist and antagonist and also genetic deletion, Leigh et al. found that

Table 2. The correlations between plasma levels of norepinephrine, epinephrine, $\beta 2-\mathrm{AR}$ gene expression and aGvHD incidence

\begin{tabular}{|c|c|c|c|c|c|c|c|c|c|c|}
\hline \multirow{3}{*}{$\begin{array}{l}\text { Day } \\
\text { aGvHD incidence }\end{array}$} & & \multicolumn{2}{|c|}{ Epinephrine } & \multicolumn{3}{|c|}{ Norepinephrine } & \multicolumn{4}{|c|}{$\beta 2-\mathrm{AR}$ relative expression } \\
\hline & & +7 & +21 & 0 & +7 & +21 & -7 & 0 & +7 & +21 \\
\hline & & & & & -0.786 & -0.845 & & & -0.63 & -0.686 \\
\hline \multirow[t]{3}{*}{ Epinephrine } & 0 & $\begin{array}{c}+0.749 \\
(.001)\end{array}$ & $\begin{array}{c}+0.541 \\
(.037)\end{array}$ & & & & & & & \\
\hline & +7 & & $\begin{array}{l}+0.806 \\
(.0001)\end{array}$ & & & & & & & \\
\hline & +21 & & & & & & & & & $\begin{array}{c}+0.616 \\
(.015)\end{array}$ \\
\hline \multirow[t]{4}{*}{ Norepinephrine } & -7 & & & $\begin{array}{l}+0.894 \\
(.0001)\end{array}$ & $\begin{array}{c}+0.701 \\
(.004)\end{array}$ & $\begin{array}{c}+0.605 \\
(.017)\end{array}$ & $\begin{array}{c}+0.741 \\
(.001)\end{array}$ & $\begin{array}{c}+0.566 \\
(.028)\end{array}$ & $\begin{array}{c}+0.755 \\
(.001)\end{array}$ & $\begin{array}{c}+0.609 \\
(.016)\end{array}$ \\
\hline & 0 & & & & $\begin{array}{c}+0.768 \\
(.001)\end{array}$ & $\begin{array}{c}+0.599 \\
(.018)\end{array}$ & $\begin{array}{c}+0.696 \\
(.004)\end{array}$ & $\begin{array}{c}+0.658 \\
(.008)\end{array}$ & $\begin{array}{l}+0.71 \\
(.003)\end{array}$ & \\
\hline & +7 & & & & & $\begin{array}{l}+0.891 \\
(.0001)\end{array}$ & & & $\begin{array}{c}+0.684 \\
(.005)\end{array}$ & $\begin{array}{c}+0.785 \\
(.001)\end{array}$ \\
\hline & +21 & & & & & & & & $\begin{array}{l}+0.74 \\
(.002)\end{array}$ & $\begin{array}{l}+0.826 \\
(.0001)\end{array}$ \\
\hline \multirow[t]{2}{*}{$\beta 2-\mathrm{AR}$ relative expression } & -7 & & & & & & & & $\begin{array}{c}+0.556 \\
(.031)\end{array}$ & \\
\hline & +7 & & & & & & & & & $\begin{array}{c}+0.596 \\
(.019)\end{array}$ \\
\hline
\end{tabular}
coefficients and the numbers in parentheses are P-values. aGvHD, acute graft-versus-host disease; $\beta 2$-AR, $\beta 2$-adrenergic receptor. 
this resistance to GvHD is due to the immune-modulation through $\beta 2$-AR signaling (8). One of the most important limitations of our study is that the $\beta 2-\mathrm{AR}$ signaling and also the expression of $\beta 2-A R$ protein were not assessed in this study. The expression of $\beta 2-A R$ mRNA cannot exactly reflect the protein level of the $\beta 2-A R$ and in the case of measuring the protein expression, the finding would be more reliable. However, the expression of $\beta 2$-AR gene and plasma levels of norepinephrine confirm the previous animal model studies. The plasma epinephrine level has no significant differences between aGvHD and Non-aGvHD patients, which perhaps indicates the greater importance of norepinephrine in neuro-immune interactions. Various studies on the role of the nervous system in progression and metastasis of different cancers have reported the elevated levels of norepinephrine but not epinephrine in their experiments $(13,17,18)$. High production of norepinephrine by macrophages and sympathetic nerves in the tumor microenvironment was brought up as a possible justification in these reports $(19,20)$. However, due to the fluctuating trend of plasma epinephrine across sampling time-points and the small sample size of our study, it is hard to completely rule out the contribution of epinephrine to the development of aGvHD.

The level of norepinephrine in subjects without aGvHD showed a high steady-state trend, while in aGvHD patients, it had a decreasing trend. This study showed the expression of the $\beta 2$-AR gene in Non-aGvHD subjects at days +7 and +21 was higher than those of aGvHD patients. $\beta 2$-AR gene expression had a gradual increase in Non-aGvHD individuals, and there were statistically significant differences across all sampling points, indicating that the $\beta 2$-AR gene expression might be playing an immunomodulatory role in Non-aGvHD patients. Interestingly, both of the significant differences in norepinephrine levels and $\beta 2$-AR gene expression between the two groups are at day +7 and +21 which suggests this period as a crucial time to follow-up the adrenergic status of patients. Surprisingly, while the norepinephrine level is generally higher in Non-aGvHD patients than aGvHD patients, there is no further increase in the norepinephrine level whilst the expression of $\beta 2-A R$ increased across all sampling time-points. This finding, which might be because of the small sample size, complicates the interactive correlation between these two components. It may be that increasing expression of $\beta 2$-AR in leukocytes could enhance the response to the high invariant levels of norepinephrine through increasing the signaling. Past studies clearly define the necessity of $\beta 2$-AR signaling along with the high norepinephrine levels in immune modulation. It was shown that by increasing the levels of norepinephrine, the phosphorylation of the $\beta 2$-AR significantly increased (13) and this effect was dependent on signaling of host-derived $\beta 2$-AR (8). Our analysis confirmed the positive correlation and probable reciprocal interaction between the norepinephrine and the expression of its receptor. As it is indicated in the results, the plasma levels of norepinephrine and the relative expression of the $\beta 2$-AR gene at days +7 and +21 are negatively correlated with the incidence of aGvHD. Noteworthy, the use of chemotherapy and immunosuppressive drugs such as cyclosporine A has been reported to affect the levels of stress hormones including norepinephrine $(21,22)$. To diminish the confounding effects of these drugs, patients using the same chemotherapeutic and immunosuppressive drugs were included in the study.

Many reported biomarkers cannot predict the outcome of the allo-HSCT before transplantation. This study shows, however, norepinephrine and $\beta 2-A R$ could potentially be predictive biomarkers. Further delineation requires larger sample size studies with more sampling time-points and also the assessment of the other adrenergic receptors which is an ongoing project in our lab.

In future studies, the roles of norepinephrine and $\beta 2-\mathrm{AR}$ signaling can be further investigated in each category of GvHD such as skin-, gastrointestinal-, and liver-GvHD. It is also necessary to follow up with the patients to assess the role of $\beta 2-A R$ signaling in the possible development of chronic GvHD and GvHD relapse. This may help elucidate the relationship between $\beta 2-A R$ signaling and stress hormones and the development of GvHD. The probable mechanisms by which the adrenergic axis could affect the outcome of GvHD is the modulation of immune cells function, specially APCs and T cells $(2,23,24)$. In the context of the tumor, Bucsek and his coworkers (25) have shown that the suppressing effect of adrenergic signaling on the anti-tumor response is mainly $\mathrm{CD} 8+\mathrm{T}$ cell-mediated and this suppression is reversible using a pan $\beta$-blocker, propranolol. Interestingly, this benefit of propranolol was lost in CD8+ T cell-depleted mice (25).

Regarding the major role of APCs and CD8+-T cells in the pathogenesis of $\operatorname{aGvHD}(26,27)$ and the expression of $\beta 2-A R$ on both activated and memory CD8+-T cells, we hypothesize that the impairment of APCs and CD8+ T cells might be a possible mechanism by which the norepinephrine and $\beta 2-A R$ signaling affect the outcome of aGvHD. This requires further investigation. The other question which should be addressed in the future is the role of $\beta 2$ AR signaling on the trafficking of immune cells to lymph nodes and non-lymphoid organs, which could be a trigger for GvHD onset. Norepinephrine and adrenergic signaling were shown to be essential mediators in the trafficking of $\mathrm{T}$ cells through chemokines and adhesion molecules (28).

\section{Conclusion}

In conclusion, further insight into the possible role of catecholamines in the development of aGvHD can be gained by the cautious use of $\beta$-blockers in allo-HSCT patients. The role of other immune-modulatory neurotransmitters in aGvHD needs a closer examination. Note the beneficial effects of GvT and the probability of losing GvT by suppressing GvHD should not be forgotten, and so it is imperative to practice caution when considering the prevention of GvHD.

\section{Acknowledgment}

The authors would like to thank all patients who participated in this study. The project was funded by Hematology and Oncology Research Center, Tabriz University of Med- 
ical Sciences, Tabriz, Iran. The study protocol received approval from the ethics committee of Tabriz University of Medical Science with the code of "IR.TBZMED.REC.1396.709".

\section{Conflict of Interests}

The authors declare that they have no competing interests.

\section{References}

1. Ringdén O, Sadeghi B. Is graft-versus-leukemia more effective using reduced-intensity conditioning compared with myeloablative conditioning? Biol Blood Marrow Transplant. 2012;18(11):1615-7.

2. Appelbaum FR. Hematopoietic-cell transplantation at 50. N Engl J Med. 2007;357(15):1472-5.

3. Eskandari F, Sternberg EM. Neural-immune interactions in health and disease. Ann N Y Acad Sci. 2002;966(1):20-7.

4. Steinman L. Elaborate interactions between the immune and nervous systems. Nat Immunol. 2004;5(6):575.

5. Kokolus KM, Spangler HM, Povinelli BJ, Farren MR, Lee KP, Repasky EA. Stressful presentations: mild cold stress in laboratory mice influences phenotype of dendritic cells in naive and tumor-bearing mice. Front Immunol. 2014;5:23.

6. Guereschi MG, Araujo LP, Maricato JT, Takenaka MC, Nascimento $\mathrm{VM}$, Vivanco BC, et al. Beta2-adrenergic receptor signaling in CD 4+ $\mathrm{F}$ oxp3+ regulatory $\mathrm{T}$ cells enhances their suppressive function in a PKA-dependent manner. Eur J Immunol. 2013;43(4):1001-12.

7. Takenaka MC, Araujo LP, Maricato JT, Nascimento VM, Guereschi MG, Rezende RM, et al. Norepinephrine Controls Effector T Cell Differentiation through 32 -Adrenergic Receptor-Mediated Inhibition of NF- $\mathrm{BB}$ and AP-1 in Dendritic Cells. J Immunol. 2016;196(2):63744.

8. Leigh ND, Kokolus KM, O’Neill RE, Du W, Eng JWL, Qiu J, et al. Housing Temperature-Induced Stress Is Suppressing Murine Graftversus-Host Disease through $\beta 2$-Adrenergic Receptor Signaling. J Immunol. 2015;1500700.

9. Kokolus KM, Capitano ML, Lee C-T, Eng JW-L, Waight JD, Hylander $\mathrm{BL}$, et al. Baseline tumor growth and immune control in laboratory mice are significantly influenced by subthermoneutral housing temperature. Proc Natl Acad Sci. 2013;110(50):20176-81.

10. Memarian A, Nourizadeh M, Masoumi F, Tabrizi M, Emami AH, Alimoghaddam K, et al. Upregulation of CD200 is associated with Foxp3+ regulatory $\mathrm{T}$ cell expansion and disease progression in acute myeloid leukemia. Tumor Biol. 2013;34(1):531-42.

11. Bakhshaei P, Kazemi MH, Golara M, Abdolmaleki S, KhosraviEghbal R, Khoshnoodi J, et al. Investigation of the Cellular Immune Response to Recombinant Fragments of Filamentous Hemagglutinin and Pertactin of Bordetella pertussis in BALB/c Mice. J Interf Cytokine Res. 2018;38(4).

12. Gholami MD, Falak R, Heidari S, Khoshmirsafa M, Kazemi MH, Zarnani $\mathrm{AH}$, et al. A truncated Snaill transcription factor alters expression of essential EMT markers and suppresses tumor cell migration in a human lung cancer cell line. Recent Pat Anticancer Drug Discov. 2019;

13. Eng JWL, Reed CB, Kokolus KM, Pitoniak R, Utley A, Bucsek MJ, et al. Housing temperature-induced stress drives therapeutic resistance in murine tumour models through $\beta 2$-adrenergic receptor activation. Nat Commun. 2015;6.

14. Jagasia MH, Greinix HT, Arora M, Williams KM, Wolff D, Cowen EW, et al. National Institutes of Health Consensus Development Project on Criteria for Clinical Trials in Chronic Graft-versus-Host Disease: I. The 2014 Diagnosis and Staging Working Group Report. Biol Blood Marrow Transplant. 2015;21(3):389-401.

15. Keating A, Wang XH, Laraya P. Variable transcription of BCR-ABL by $\mathrm{Ph}+$ cells arising from hematopoietic progenitors in chronic myeloid leukemia. Blood [Internet]. 1994;83(7):1744-9. Available from: http://www.ncbi.nlm.nih.gov/pubmed/8142641

16. Rao X, Huang X, Zhou Z, Lin X. An improvement of the $2 \wedge$ (-delta delta $\mathrm{CT}$ ) method for quantitative real-time polymerase chain reaction data analysis. Biostat Bioinforma Biomath. 2013;3(3):71.

17. Lutgendorf SK, DeGeest K, Dahmoush L, Farley D, Penedo F, Bender $\mathrm{D}$, et al. Social isolation is associated with elevated tumor norepinephrine in ovarian carcinoma patients. Brain Behav Immun.
$2011 ; 25(2): 250-5$.

18. Bellinger DL, Lorton D. Autonomic regulation of cellular immune function. Vol. 182, Autonomic Neuroscience: Basic and Clinical. 2014. p. $15-41$.

19. Magnon C, Hall S, Lin J, Xue X, Gerber L, Freedland S, et al. Autonomic Nerve Development Cancer Progression. Science (80- ) 2013;341:1-10.

20. Nguyen KD, Qiu Y, Cui X, Goh YPS, Mwangi J, David T, et al. Alternatively activated macrophages produce catecholamines to sustain adaptive thermogenesis. Nature. 2011;480(7375):104-8.

21. Pei Y, Richardson R, Greenwood C, Wong PY, Baines A. Extrarenal effect of cyclosporine A on potassium homeostasis in renal transplant recipients. Am J Kidney Dis. 1993;22(2):314-9.

22. Shimizu H, Kumai T, Kobayashi S. Involvement of tyrosine hydroxylase upregulation in cyclosporine-induced hypertension. Jpn J Pharmacol. 2001;85(3):306-12.

23. Yanagawa Y, Matsumoto M, Togashi H. Enhanced Dendritic Cell Antigen Uptake via 2 Adrenoceptor-Mediated PI3K Activation Following Brief Exposure to Noradrenaline. J Immunol [Internet]. 2010;185(10):5762-8. Available from: http://www.jimmunol.org/cgi/ doi/10.4049/jimmunol.1001899

24. Herve J, Dubreil L, Tardif V, Terme M, Pogu S, Anegon I, et al. 2 Adrenoreceptor Agonist Inhibits Antigen Cross-Presentation by Dendritic Cells. J Immunol [Internet]. 2013;190(7):3163-71. Available from: http://www.jimmunol.org/cgi/doi/10.4049/jimmunol. 1201391

25. Bucsek MJ, Qiao G, MacDonald CR, Giridharan T, Evans L, Niedzwecki B, et al. $\beta$-Adrenergic signaling in mice housed at standard temperatures suppresses an effector phenotype in CD8+T cells and undermines checkpoint inhibitor therapy. Cancer Res. 2017;77(20):5639-51.

26. Shlomchik WD. Graft-versus-host disease. Nat Rev Immunol. 2007;7(5):340.

27. Shlomchik WD, Couzens MS, Tang CB, McNiff J, Robert ME, Liu J, et al. Prevention of graft versus host disease by inactivation of host antigen-presenting cells. Science. 1999;285(5426):412-5.

28. Scheiermann C, Kunisaki Y, Lucas D, Chow A, Jang JE, Zhang D, et al. Adrenergic nerves govern circadian leukocyte recruitment to tissues. Immunity. 2012;37(2):290-301. 